\title{
The Influence of the Strength of Financial Institutions and the Investment-Production Delay on Commodity Price Cycles: A Framed Field Experiment with Coffee Farmers in Colombia
}

\author{
Santiago Arango-Aramburo ${ }^{1} \cdot$ Yuliana Acevedo $^{1} \cdot$ Joep Sonnemans $^{2,3} \mathbb{D}$
}

Published online: 14 June 2019

(c) The Author(s) 2019

\begin{abstract}
Commodity price cycles can arise when there is a tendency to invest more (less) when current prices are high (low). Traditionally this behavior is interpreted as based upon naïve expectations. However, weak financial institutions can also cause this behavior. When borrowing is hard and saving is risky farmers cannot invest in periods with low prices because their income is too low, while in periods with high prices they have few alternatives than to invest the surplus in their farm. In this paper, we present a framed field experiment to analyze how Colombian smallscale coffee farmers make investment decisions. We vary the strength of the financial institutions and the lag between investment and production. Overall there is a positive relation between prices and investment, and this relation becomes stronger when the financial institutions become weaker.
\end{abstract}

Keywords Cobweb $\cdot$ Coffee planting $\cdot$ Framed field experiment $\cdot$ Financial institutions · Price cycles

JEL Classification C91 $\cdot \mathrm{O} 13 \cdot \mathrm{Q} 14$

Joep Sonnemans

j.h.sonnemans@uva.nl

1 Decision Sciences Group Faculty of Mines, Universidad Nacional de Colombia, Carrera 80 \# 65-223, Bloque M8a-211, Medellin, Colombia

2 CREED, Amsterdam School of Economics, University of Amsterdam, P.O. Box 15867, 1001 NJ Amsterdam, The Netherlands

3 The Tinbergen Institute, Amsterdam, The Netherlands 


\section{Introduction}

Commodity prices typically show high volatility of prices and price cycles. Price fluctuations are generally thought to have significant negative effects for consumers and producers, particularly for developing countries (Akiyama et al. 2001, 2003; Deaton 1999; Varangis et al. 1996). The variability and cycles in commodity prices are topics that have occupied economists for a long time from Tinbergen (1930) and Ezekiel (1938). In the classic cobweb models high volatility of prices and price cycles were explained by the presence of naïve producers, who tend to invest more (less) when prices are high (low). Previous laboratory experiments have shown that most decision-makers are not that naïve, and that prices converge fast to the equilibrium when the lag between investment and production is short (Hommes et al. 2007). Arango et al. (2013), Arango and Moxnes (2012), and Kampmann and Sterman (2014) showed that prices do not converge in more complicated situations with a longer lag between investment and start of production, and multi-period production.

A second cause of price cycles may be imperfect financial institutions. When financial institutions are functioning imperfectly, a small-scale producer has limited access to credit in bad times, while at good times saving money is risky because of the possibility of banks defaults or extreme inflation. When prices are low, such producer has a low income that will be needed for maintenance and living expenses, while credit is hard to get and thus investment will be impossible. On the other hand, when prices are high the producer has a surplus of money. Depositing this money in a bank is risky and the producer will be tempted to invest this money in his business. In such situation even non-naïve producers will under-invest when prices are low and over-invest when prices are high, which will lead to price cycles.

We studied the investment decisions of Colombian small-scale coffee farmers in a framed field experiment (Harrison and List 2004). In a $2 \times 3$ design we vary the lag between investment and first production (short-long) and the quality of financial institutions (strong-weak-very weak). In the ideal design we would study groups of producers who make investment decisions in a series of periods, which would determine the production in later periods, which in turn would determine realized prices. However, implementing such feedback design proved to be practical impossible, because in such design we would need many producers at the same time at the same place and it would provide us with only few independent observations per treatment. Therefore, an individual decision-making task was implemented. In each of 25 periods the participants first learn the current price and then make an investment decision. These investments start producing after a short or long lag and are sold for the market price of that period. The earnings of the participants are based on the sale of the product for the market price of the period of production, minus the cost of investment and maintenance. The market prices are based upon historical prices. Interest on loans (deposits) is subtracted from (added to) the earnings. Overall, we find a positive relation between prices and investment, and this relation becomes stronger when the financial institutions become weaker. 
In the next section the background of the coffee industry will be sketched; Sect. 3 introduces the dynamic model; Sect. 4 describes the experimental design and procedures; the results are presented in Sects. 5 and 6 concludes.

\section{Coffee in Colombia}

Colombia is the third country in global coffee production (ICO 2017). It has about 904 thousand hectares of coffee plantation, with 14 million bags per year of production, of which around $91 \%$ is exported (FNC 2017). The coffee sector is the main agricultural product for Colombian economy, generating more than 800 thousand direct and indirect jobs, close to $30 \%$ of the rural employment rate. Five hundred thousand families are dedicated to growing coffee and they are organized in the Federación Nacional de Cafeteros de Colombia (FNC), which sets minimum producer prices, controls the purchasing, the processing and the exportation of coffee.

The income of coffee producers faces uncertainty due to cyclical price behavior (Mehta and Chavas 2008). For example, in 2011, the domestic price of coffee was COP $\$ 9068 / \mathrm{kg}$, the highest price ever, thereafter, the price decreased to stand at COP $\$ 3000 / \mathrm{kg}$ in 2013 . This situation connected to other factors such as the international coffee price drop, the Colombian peso revaluation, the winter, caused strikes by farmers (Rodríguez 2013). In response to the fall in coffee prices, a coffee producers' program was implemented as a subvention when the domestic purchase price of the coffee is below COP $\$ 5600 / \mathrm{kg}$. Finally, during 2014 , the price began to recover and it went up to COP $\$ 6208 / \mathrm{kg}$.

In addition to the dynamic complexity of the price, there is another element of dynamics which farmers have to deal with: Coffee is a long-term crop, because after planting it takes approximately 3 years to the first harvest. The plant is productive for about 5 years, after which it has to be replaced. In addition, between harvests the producers do not earn incomes (Lozano 2009). Therefore, farmers must balance their budget in times of scarcity when they have low incomes and high input and maintenance costs (Sadoulet and De Janvry 1995). Consequently, producers need to form mental models about how the market works when they make decisions. The dynamic complexity of the market and the inadequate mental models, combined with the low educational level, lack of long-term vision and poverty, make it hard for farmers to save money in bonanza time. This is reflected in their financial results and investment decisions (Lewin et al. 2004). 
Table 1 Experimental treatments
Financial institutions

Interest on deposits-loans

\begin{tabular}{lll}
\hline Strong & Weak & Very weak \\
$3-5 \%$ & $5-11 \%$ & $0 \%$-no borrowing
\end{tabular}

Investment delay

\begin{tabular}{llll} 
Short (1 period) & StrongS & WeakS & VWeakS \\
Long (3 periods) & StrongL & WeakL & VWeakL \\
\hline
\end{tabular}

\section{Experiment Design and Procedures}

\subsection{Participants}

The experiment was conceived as a framed field experiment (Harrison and List 2004). In order to strengthen the external validity of the experiment, we use Colombian coffee farmers as participants. In Colombia $96 \%$ of the plantations have a size below 5 ha (FNC 2017). The 120 participants in our experiment are small-scale farmers (63\% have less than 3 ha), in the Andes and Jardín (traditional coffee growing municipalities in Colombia). Participants were recruited through the local organizations. They typically had a low level of education (40\% did not complete their primary education) and a long experience with coffee farming (on average over 20 years).

\subsection{The Investment Task}

In each of the 25 periods the only decision a participant has to make, is how many new coffee trees to plant. The total number of plants is limited by the size of the plantation, 5000 in the experiment. One period in the experiment is equivalent to 1 year in the real world. The first 1 or 3 periods (depending on the treatment) the trees will not yet produce coffee, and after that they will produce for 5 years $0.5 \mathrm{~kg}$ per period per tree. After the 5 productive periods the tree will be removed (without costs). The coffee that is produced will be sold to the market, at the price of that period and the earnings are added to the balance, the prices is given per "carga" ("carga" is the equivalent of 2 sacs of coffee or $125 \mathrm{~kg}$ ) which is common use in Colombia. The total costs are the costs of planting (COP \$1700/plant), the cost of maintaining the trees (COP \$2000/plant in each period) and costs of interest on debt minus the interest earned on saving deposits (interest rates differ between treatments; see Table 1). Whether there is a debt or a saving deposit depends on the cash balance. If the cash balance is positive after payment of costs and interest, interest will be paid. If the cash balance is negative, investment or maintenance costs will be added to the debt, and once the balance is positive, the interest on the debt is paid. The deadline to repay the loan is one period. If the cash balance is still negative, they can continue borrowing and interest are accrued over the debt. In all treatments, 
subjects have the possibility to add debt with no restrictions, i.e. there is no bankruptcy in the experiment, except in the weakest financial institution treatment. In the later, there is no access to loans and it is thus impossible to plant if the cash balance is insufficient to cover the investment costs. In the experiment, the initial balance of money was COP $\$ 25,000,000$.

Information is presented to the user through a computer interface. The participant observes all relevant information: the number of plants that are producing or not yet producing, the harvest, current price, income and expenses, the balance of accumulated money and the maximum number of coffee trees that can be planted in the period.

\subsection{Treatments}

A $2 \times 3$ design is employed (see Table 1); farmers were randomly assigned to only one treatment (a between-subjects design was employed). The delay between investment and production is either 1 or 3 periods. Coffee is a long-term crop, and the time between planting and the first harvest is approximately 3 years. We consider different delays as treatment variable, because previous experiments showed less stable market prices in case of longer delays, which could have been caused by a stronger correlation between investments and current prices, but it could also be caused by the more complex feedback systems (Arango and Moxnes 2012). In the treatment with a delay of only one period, we try to "remove" the dynamic complexity of the crop.

The strength of the financial institutions is varied on three levels. In the strong financial institution treatment the interest rates for deposits and loans are 3\% and 5\% respectively. The weak financial institution treatment combines higher interest rates with a larger gap (spread) between the interest on loans and deposits (11\% and 5\%). Finally, in the very weak financial institution treatment borrowing is impossible for farmers, a situation that is not uncommon for small farmers in developing countries. For the sake of simplicity, the experiment considers an economic system with no inflation, and thus, we have all real prices and interest rates. In reality, the most common situation is the weak institution in the coffee regions (in particular the one where the experiment was applied). Therefore, we move to a better condition with the strong treatment, and we move to a worse condition with the very weak treatment.

\subsection{Procedures}

Because many farmers are not accustomed to using a computer, we assigned a facilitator to each participant. The facilitator was responsible for reading and explaining the game instructions to each person, handling the interface, entering decisions for each round and presenting the results. We started with 5 practice periods without financial consequences, after which we restarted with the 25 incentivized periods.

At the end of the game, each subject was privately paid with real Colombian pesos for participation in the experiment. The payments were made on the basis of the accumulated cash balance during all periods of the game, using a fixed exchange from experimental pesos to real Colombian pesos plus a participation fee of COP $\$ 20,000$. 
Earnings in real cash were between COP \$20,000 and COP \$ 60,000 (i.e. about 10 US\$-30 US\$). This amount is about one to three times the average earnings per harvest day according to Valencia (2010).

\section{Hypotheses}

Price cycles arise when the producers tend to invest more (less) when the price of the commodity is higher (lower). Our first hypothesis is about the influence of the financial institutions on this tendency.

Hypothesis 1 When institutions are weaker, the positive relation between price and investment will be stronger.

From previous experimental research we know that markets are less stable when the delay between investment and production is higher (Arango and Moxnes 2012; Arango et al. 2013; Kampmann and Sterman 2014). This may be caused by a stronger positive relation between price and investment.

Hypothesis 2 When the delay between investment and production is longer, the positive relation between price and investment will be stronger.

\section{Results}

Typically, the participants started with investing much in the first period and after that they tried to distribute the planting over several periods to ensure a harvest in every period. In every period in which plants expired, they replanted to some extent (Fig. 1). This is much in line with behavior outside the experiment; stopping planting would mean ending a business that has passed from generation to generation. As expected we observe in Fig. 1 a shorter investment cycle in the short delay treatments, which is caused by difference in the length of the life cycles of plants: 6 periods ( 1 unproductive +5 productive) for the short delay and 8 periods ( 3 unproductive +5 productive) for long delay.

Table 2 shows the average investments in the treatments. Average investments are higher in the Short-treatments, where a replacement for investments would take place every 6 periods (years) in the Short delay and every 8 periods in the Long delay treatment. When we correct for this, by multiplying the investments in the short delay treatments by 6/8, the difference between the Short and Long delay treatments is no longer significant. ${ }^{1}$ We expected less investment when the financial

\footnotetext{
1 The overall difference between these corrected investments is not statistically significant between short and long delay. For the separate financial institutions, we find that the corrected investments are significantly smaller (larger) in the short than in the long delay when the financial institutions are Strong (Very Weak) and we find no difference when the institutions are Weak.
} 


\section{Price}

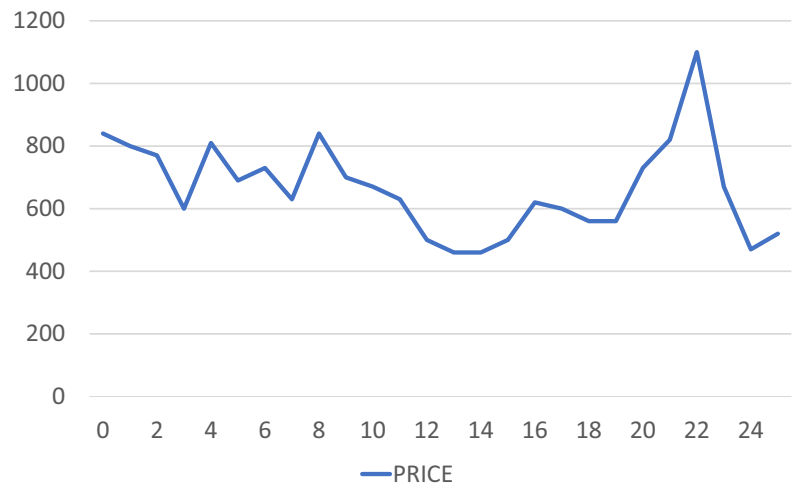

\section{Short Delay}

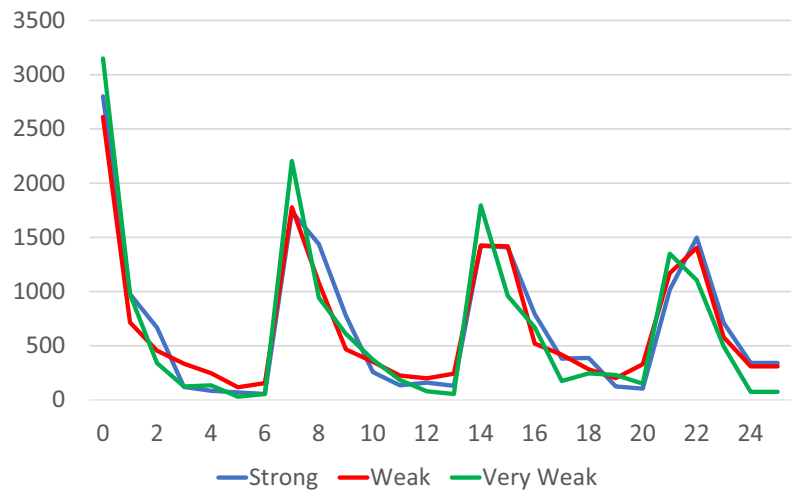

\section{Long Delay}

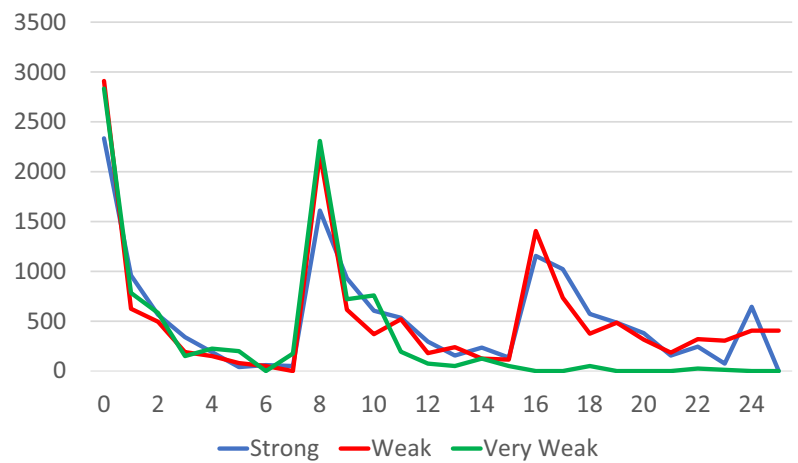

Fig. 1 Average investments over the periods. Price is in $1000 \mathrm{COP} \$$ per $125 \mathrm{~kg}$ 
Table 2 Average investments

\begin{tabular}{|c|c|c|c|c|c|c|}
\hline & \multicolumn{5}{|c|}{ Financial institutions } & \multirow[t]{2}{*}{ Total } \\
\hline & \multicolumn{2}{|l|}{ Strong } & \multicolumn{2}{|l|}{ Weak } & \multirow[t]{2}{*}{ Very weak } & \\
\hline & Investm & ent $d$ & & & & \\
\hline \multirow[t]{2}{*}{ Short } & 690 & ns & 667 & ns & 638 & 665 \\
\hline & $>* *$ & & $>* *$ & & $>* * *$ & $>* * *$ \\
\hline Long & 551 & $>^{\#}$ & 530 & $>* * *$ & 358 & 479 \\
\hline Total & 622 & ns & 599 & $>* *$ & 498 & 573 \\
\hline
\end{tabular}

Two-sided Mann-Whitney tests on average individual investment $\#, *, * *, * * *$ denotes statistical significance on $0.10,0.05,0.01,0.001$ respectively and ns denotes no statistical significance

Table 3 Tobit regression of the investment on the treatment variables and their interactions

\begin{tabular}{|c|c|c|c|c|}
\hline & \multicolumn{4}{|c|}{ Dependent variable: investment } \\
\hline & (1) & (2) & (3) & (4) \\
\hline Current price & $\begin{array}{l}3.42 * * * \\
(.357)\end{array}$ & $\begin{array}{l}2.69 * * * \\
(-.475)\end{array}$ & $\begin{array}{l}3.10 * * * \\
(.398)\end{array}$ & $\begin{array}{l}2.34 * * * \\
(.558)\end{array}$ \\
\hline Long delay & $\begin{array}{l}-576^{* * * *} \\
(109)\end{array}$ & $\begin{array}{l}-679 * * * \\
(110)\end{array}$ & $\begin{array}{l}-1178 * * \\
(445)\end{array}$ & $\begin{array}{l}-1211^{* *} \\
(426)\end{array}$ \\
\hline Weak Fin. institutions & $\begin{array}{l}-123 \\
(133)\end{array}$ & $\begin{array}{l}-331 \\
(492)\end{array}$ & $\begin{array}{l}-122 \\
(132)\end{array}$ & $\begin{array}{l}-333 \\
(500)\end{array}$ \\
\hline Very weak Fin. institutions & $\begin{array}{l}-642 * * * \\
(130)\end{array}$ & $\begin{array}{l}-2069 * * * \\
(522)\end{array}$ & $\begin{array}{l}-642^{* * * *} \\
(131)\end{array}$ & $\begin{array}{l}-2083^{* * * *} \\
(517)\end{array}$ \\
\hline Weak Fin. Inst. * Price & & $\begin{array}{l}.306 \\
(.599)\end{array}$ & & $\begin{array}{l}.296 \\
(.606)\end{array}$ \\
\hline Very weak Fin. Inst. * Price & & $\begin{array}{l}2.09 * * * * \\
(.637)\end{array}$ & & $\begin{array}{l}2.10 * * * \\
(.630)\end{array}$ \\
\hline Long delay $*$ Price & & & $\begin{array}{l}.735 \\
(.545)\end{array}$ & $\begin{array}{l}.781 \\
(.514)\end{array}$ \\
\hline Constant & $\begin{array}{l}-2405 * * * \\
(347)\end{array}$ & $\begin{array}{l}-1902 * * * \\
(430)\end{array}$ & $\begin{array}{l}-2186 * * * \\
(374)\end{array}$ & $\begin{array}{l}-1668 * * * \\
(480)\end{array}$ \\
\hline
\end{tabular}

The numbers in parentheses are robust standard errors, clustered per participant. 3100 observations, of which 1941 left-censored (investment $=0$ )

** (***) denotes statistical significance on the 0.01 (0.001) level

institution is Weak or Very Weak, because borrowing becomes more expensive or even impossible while the return on a deposit is higher. This effect is not observed in the Short delay treatments. In the Long delay treatments, the difference between Strong and Weak financial institution is marginally significant and between Weak and Very Weak is highly significant. These results are also observed in a Tobit regression, see column (1) of Table 3.

The most interesting question is about the relation between price and investments. A positive relation (high investments when prices are high and low investments when prices are low) would lead to less stable markets and prices cycles. The 
Tobit regressions displayed in Table 3 show statistically significant positive relations between price and investment. In column (2) and (3) we look at the interaction effects of the treatment variables with price and column (4) combines both interaction effects. The conclusion is straightforward: investment is positively correlated with the price and this relationship is stronger when the financial institutions are very weak.

Returning to our hypotheses, we conclude that the results are in line with Hypothesis 1: we indeed find a stronger relation between price and investment when financial institutions are very weak. We have to reject Hypothesis 2: we do not find a stronger relation between price and investment when the delay is long. This is an interesting finding, because it suggests that the instability of markets with a long delay may have other causes, such as the existence of accumulation or carry-overs, and more complex feedback mechanisms (Arango and Moxnes 2012; Arango Aramburo et al. 2012; Arango et al. 2013; Kampmann and Sterman 2014).

Finally, we take a look at the borrowing and saving behavior. In the long treatments, $38 \%$ and $44 \%$ of the investments in new plants are (partly) financed by loans in respectively the strong and weak financial institutions treatments. This difference is not statistically significant (Mann-Whitney test, 2-sided $p=0.2$ ). The impossibility to borrow makes the Very Weak Long delay treatment very hard for the farmers, as can be seen in Fig. 1. Most farmers do not invest anymore in the second half of the experiment because they have too little money.

In the short treatment (which is easier to finance because of the shorter delay) borrowing is rarer: 7\% (strong) and 0\% (weak), (Mann-Whitney test, 2-sided $p=0.01$ ). In the very weak financial institutions treatment borrowing is not possible, and no interest is received on savings. Comparing the weak with the very weak financial institutions in the short treatments, the (im)possibility of borrowing should not make a difference, because in the weak treatment borrowing did not occur. However, we find that 12 of the 20 participants in the very weak treatment are technically bankrupt in the last period, against only 5 of 20 in the weak treatment. This suggest that the $0 \%$ saving interest in the very weak treatment induces farmers to invest in plants whenever they have a positive balance, while they cannot always afford the maintenance costs in periods with a low return.

\section{Conclusions}

We studied the investment decisions of Colombian small-scale coffee farmers in a framed field experiment. We find overall a positive relation between current price and investment, and this relation becomes stronger when financial institutions are very weak. Interestingly, a shorter lag did not statistically significant decrease the strength of this relation.

Our study suggests that stronger institutions that provide small farmers with the possibility of taking loans when prices are low and reliable saving when prices are high would weaken the positive correlation between current price and investment, and thus indirectly decrease price volatility. Of course, prices of agricultural 
commodities will always fluctuate because of the weather and crop illnesses, but improvement of the financial infrastructure could decrease these fluctuations.

When financial institutions are weak, which is not uncommon in developing countries, in low price periods small farmers have a low income and may have trouble borrowing money to invest, while in high price periods they will have a surplus of money that they can only invest in their farm because saving deposits are too risky and alternative options are limited. In that case, also the investments of farmers who do not have naïve expectations about future prices will be positively related to the current price.

Finally, we would like to suggest some directions for future research. In the present study, the strength of financial institutions is varied in both the possibility and interest rate of borrowing and the interest rate of saving. It could be interesting to study the separate effect of borrowing and saving limitations. Second, cobweb models so far ignore the opportunity costs, and it would be interesting to include alternative land use for not-planted areas.

Acknowledgements The authors are grateful to the Universidad Nacional de Colombia (Project: 200000013697) and to the Antioquia Government for the financial support. We also thank Adrián Saldarriaga, Karoll Gómez, Clara Villegas, Ailko van de Veen, and Randolph Sloof for their constructive comments.

Open Access This article is distributed under the terms of the Creative Commons Attribution 4.0 International License (http://creativecommons.org/licenses/by/4.0/), which permits unrestricted use, distribution, and reproduction in any medium, provided you give appropriate credit to the original author(s) and the source, provide a link to the Creative Commons license, and indicate if changes were made.

\section{Appendix: Instructions (Translated from Spanish)}

The following instructions correspond to the treatment with short delay and strong financial institutions of our experiment. The delay and financial institutions values were changed according to the applied treatment.

"Today, we would like to conduct an experiment with you, it takes about $1 \mathrm{~h}$ and you will have the opportunity to earn cash, which depends on your decisions during the experiment.

The experiment tries to recreate a situation in which a small farmer must manage their crop to get the most money possible.

You represent a farmer who owns a farm, where you can plant 5000 coffee trees, maximum. You must decide for 25 years, how many trees to plant. The plants take 1 year to grow, and in this period will produce nothing. Once trees begin to produce, they will do for 5 years.

The cash balance increases with income and decreases with the costs obtained for each year. Revenues depend on the crop and the price of the coffee load. The harvest depends on the number of trees in production and productivity [1 lbs/coffee tree]. The price of the coffee load ranges between COP $\$ 400,000$ and COP $\$ 1,100,000$.

$$
\text { Cash balance }=\text { Initial Cash balance }+ \text { Incomes }- \text { Costs }
$$




\section{Incomes $=$ Harvest $\times$ Price \\ Harvest $=$ \#trees in production $\times$ productivity}

The costs are a function of maintenance, loan repayment and investment in planting.

$$
\begin{gathered}
\text { Costs }=\text { Maintenance }+ \text { Investment in planting } \\
\text { Maintenance }=\text { Coffee tree planted } \times \text { Maintenance per coffee tree } \\
\text { Investment cost }=\# \text { Coffee tree to be planted } \times \text { Cost of invetment planting }
\end{gathered}
$$

The cost of planting is COP $\$ 1700$ per coffee tree and the annual COP $\$ 2000$ per coffee tree. If balance is not enough to cover costs, a loan is granted to an interest annual rate of $5 \%$, which will be paid once the balance is positive.

If you decide not to invest in planting and you have a balance of money available, it will have a yield of $3 \%$ annual.

During each year, you will know the number of trees growing; number of trees in production, price, harvest, income and cost of the year, the accumulated balance of money during different years and the number of trees to be planted. Information will be provided as follows:

\section{DECISIONS}

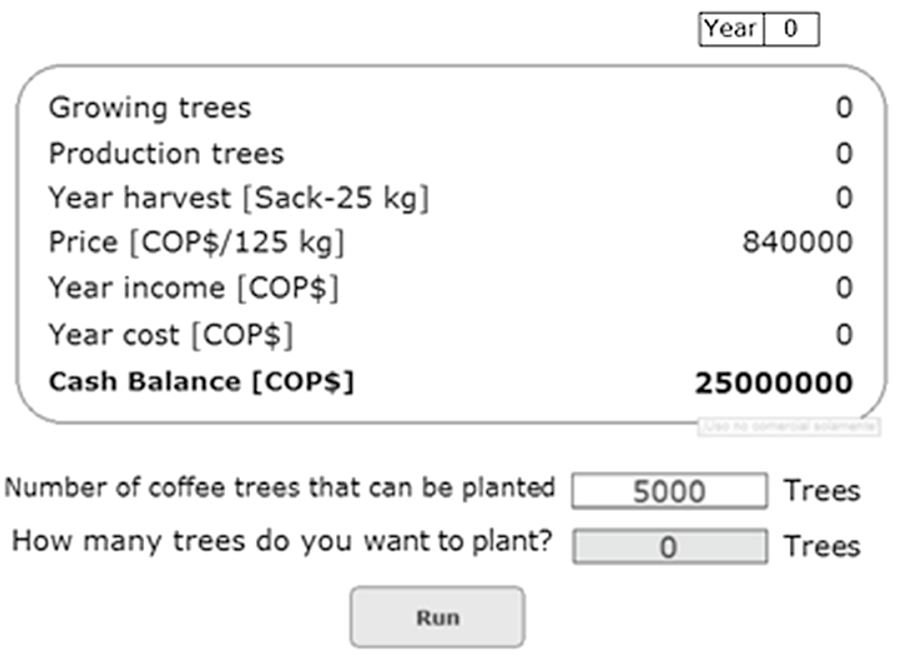

Also, you have an initial balance of COP \$25 million, which can be used to pay the costs of planting and crop maintenance. In the gray box, you must decide how many trees to plant, taking into account that you only have space for 5000. Once you decide how many trees to plant, press "Run" for next year. 
When the experiment ends, we will proceed to pay for your participation. The cash payments range is between COP $\$ 20,000$ and $\$ 60,000$. Remember that the more money your balance, the higher your payment."

\section{References}

Akiyama, T., Baffes, J., Larson, D. F., \& Varangis, P. (2003). Commodity market reform in Africa: Some recent experience. Economic Systems, 27, 83-115. https://doi.org/10.1016/S0939-3625(03)00018-9.

Akiyama, T., Larson, D. F., \& Varangis, P. (2001). Commodity market reforms: Lessons of two decades. Washington, DC (EUA): Banco Mundial.

Arango Aramburo, S., Castañeda Acevedo, J. A., \& Olaya Morales, Y. (2012). Laboratory experiments in the system dynamics field. System Dynamics Review, 28, 94-106. https://doi.org/10.1002/sdr.472.

Arango, S., Castañeda, J. A., \& Larsen, E. R. (2013). Mothballing in power markets: An experimental study. Energy Economics, 36, 125-134. https://doi.org/10.1016/j.eneco.2012.11.027.

Arango, S., \& Moxnes, E. (2012). Commodity cycles, a function of market complexity? Extending the cobweb experiment. Journal of Economic Behavior \& Organization, 84, 321-334. https://doi. org/10.1016/j.jebo.2012.04.002.

Deaton, A. (1999). Commodity prices and growth in Africa. Journal of Economic Perspective, 13, $23-40$. https://doi.org/10.1257/jep.13.3.23.

Ezekiel, M. (1938). The cobweb theorem. The Quarterly Journal of Economics, 52, 255-280.

FNC. (2017). Coffee statistics [WWW Document]. http://www.federaciondecafeteros.org/particulares/es/ quienes_somos/119_estadisticas_historicas/. Accessed 20 July 2018.

Harrison, G. W., \& List, J. A. (2004). Field experiments. Journal of Economic Literature, 42, 1009-1055. https://doi.org/10.1257/0022051043004577.

Hommes, C., Sonnemans, J., Tuinstra, J., \& Van De Velden, H. (2007). Learning in cobweb experiments. Macroeconomic Dynamics, 11, 8-33.

ICO. (2017). Total production by all exporting countries [WWW Document]. http://www.ico.org/prices/ po-production.pdf. Accessed 20 July 2018.

Kampmann, C. E., \& Sterman, J. D. (2014). Do markets mitigate misperceptions of feedback? System Dynamics Review, 30, 123-160. https://doi.org/10.1002/sdr.1515.

Lewin, B., Giovannucci, D., \& Varangis, P. (2004). Coffee markets: New paradigms in global supply and demand. World Bank Agriculture and Rural Development Discussion Paper.

Lozano, Andrés. (2009). Acceso Al Crédito En El Sector Cafetero Colombiano. Ensayos Sobre Economía Cafetera, 25, 95-121.

Mehta, Aashish, \& Chavas, Jean-Paul. (2008). Responding to the coffee crisis: What can we learn from price dynamics? Journal of Development Economics, 85(1), 282-311.

Rodríguez, Edwin Cruz. (2013). Todos Somos Hijos Del Café': Sociología Política Del Paro Nacional Cafetero. Entramado, 9(2), 138-158.

Sadoulet, Elisabeth, \& De Janvry, Alain. (1995). Quantitative development policy analysis. Baltimore: Johns Hopkins University Press.

Tinbergen, J. (1930). Bestimmung und Deutung von Angebotskurven Ein Beispiel. Zeitschrift für Nationalo, 1, 669-679. https://doi.org/10.1007/BF01318500.

Valencia, R. (2010). Responsabilidad social empresarial y estatal frente al manejo del talento humano en el sector productivo cafetero. Manizales: Universidad Nacional de Colombia (in Spanish).

Varangis, P., Akiyama, T., \& Mitchell, D. (1996). Managing commodity booms and busts. The World Bank. https://doi.org/10.1596/0-8213-3489-1.

Publisher's Note Springer Nature remains neutral with regard to jurisdictional claims in published maps and institutional affiliations. 